\title{
Analyses of Heavy Construction Equipment Accidents and Safety Prevention
}

\author{
${ }^{* 1}$ Niyazi Bilim, ${ }^{1}$ Bilgehan Kekec and ${ }^{2}$ Atiye Bilim \\ ${ }^{* 1}$ Faculty of Engineering and Natural Sciences, Department of Mining Engineering, Konya Technical University, \\ Turkey \\ ${ }^{2}$ Vocational School of Technical Sciences, Department of Occupational Health and Safety Programme, Konya \\ Technical University, Turkey
}

\begin{abstract}
Equipment-related occupational accidents are very higher when compared to all other type occupational accidents in the worldwide. Various types and styles of many equipment are used in construction industries (construction and mining). This equipment are usually huge and heavy, so the consequences of accidents are severe. Occupational accidents related this equipment might occur due to operating faulty, carelessly and unserviceably. In this study, the causes of occupational accidents related with heavy equipment in construction workplaces are presented and cause-and-effect relationships of occupational accidents are investigated based on the statistics. Heavy equipment safety types are analysed for incident prevention by statistics. In addition, the detailed information are presented about the precautions to prevent such accidents. As a result, all stakeholders should pay attention to the use of new security technologies and to reduce human default to prevent workplace injuries depending on the equipment.
\end{abstract}

Key words: Heavy equipment safety; equipment safety, equipment accident, occupational safety, construction safety

\section{Introduction}

Machines are a critical part of our lives. They take various forms and allow people to work with less effort and improve production efficiency. Numerous types of heavy construction equipment are available for use to contractors from different industries, such as mining and construction, for performing a wide variety of work activities. Different types of heavy construction equipment are used different types of projects, or work activities at different levels (Kazan, 2013). One of every five-workplace fatalities is a construction worker (OSHA, 2018). However, without proper safeguarding and controls, physical contact with machines and powered equipment can result in severe workplace injuries and deaths (Marsh and Fosbroke, 2015). The Bureau of Labor Statistics of fatal occupational Injuries identified 761 contact with object and equipment related deaths on construction sites in 2016. 970 person were also died in construction and extraction sector and when the incidence rates were examined, this sector becomes in third row, (12.4). McCann (2006) reported in the study about excavation industry between 1992-2006 years in the United States that moving vehicle incidents are $53 \%$ and struck by objects are $24 \%$ of vehicle related deaths on construction site. Besides, the half of deaths in excavation industry are actualized about heavy equipment-related incidents on construction sites. Workers on construction sites often find themselves with dangerous and life-threatening conditions.

*Corresponding author: Address: Faculty of Engineering and Natural Sciences, Department of Mining Engineering, Konya Technical University, Turkey 


\section{Materials and Method}

Working on or around heavy equipment is high-risk work. If an incident occurs, the result is often a life-altering injury such as a broken bone, head injury, or, in many cases, loss of life. Incidents involving heavy equipment deeply affect not only the person who is injured but also the person operating the equipment or any co-workers nearby (ihsa.ca).

In the USA, 54\% of fatal accidents occurred in mine operations in the last 10 years are due to mining equipment. (Table 1). In Table 1, considering that approximately half of work accidents occurring in mining operations are due to the use of mining equipment, it is obvious that a special prevention and importance is required to reduce the accidents related with the equipment.

Table 1. The ratio of fatal accidents to equipment accidents occurred in mines in the USA in the last 10 years (msha.gov)

\begin{tabular}{cccc}
\hline Years & $\begin{array}{c}\text { Equipment } \\
\text { Related Fatality }\end{array}$ & All Fatality & $\begin{array}{c}\text { Rate } \\
(\%)\end{array}$ \\
\hline 2006 & 35 & 73 & 47,9 \\
2007 & 25 & 67 & 37.3 \\
2008 & 31 & 53 & 58.5 \\
2009 & 17 & 35 & 48,6 \\
2010 & 29 & 71 & 40.8 \\
2011 & 4 & 36 & 11.1 \\
2012 & 31 & 36 & 86.1 \\
2013 & 34 & 42 & 81,0 \\
2014 & 35 & 46 & 76.1 \\
2015 & 15 & 29 & 51.7 \\
\multicolumn{2}{c}{ Average } & $\mathbf{4 8 . 8}$ & $\mathbf{5 3 . 9}$
\end{tabular}

\subsection{Reasons for Heavy Equipment Accidents}

Occupational accidents frequently encountered in heavy construction equipment can be listed as follows:

- Struck-by: this accident take place any time a worker is struck or hit by any type of equipment, moving load/material, attachment, and object (Hinze et. al., 2005).

- Falling from vehicle

- Electric shock (electrocution)

- Caught or compressed in running equipment or machinery

- Crushing (run-over): damage of operator or other person by heavy construction equipment

Where heavy construction equipment is used, the following safety precautions should be observed:

Communication: A signaler or spotter is another set of eyes for the equipment operator. However, often the spotter is the worker most in danger of being struck by moving equipment. Workers who 
are designated as spotters should stand where equipment operators can see them at all times and have a full view of the intended path of travel. They must not only stay out of the path of the vehicle they are signalling for but also be aware of other moving machinery in the area.

Blind Spots: Every worker on the jobsite should know where the blind spots are located on different types of vehicles. Heavy equipment operators have to be $100 \%$ sure that no one is behind them or in their blind spots when moving, even if this involves getting out of the machine and checking. If workers know where the blind spots are, they can avoid them. A good practice is to maintain eye contact with a driver or operator when working near heavy equipment. If vision is limited, have a spotter stand in a safe, visible position to guide and direct you. Around for the day of your blind spots the workers must be informed and require them to make eye contact with signaller before coming in the equipment's vicinity. High visibility vests are mandatory on all sites.

Loading/Unloading Equipment: Workers are always sure to be on level ground when loading or unloading your equipment. If you are unloading on a busy jobsite or high traffic area, Make sure people are clear of the unloading area and use a spotter to guide.

Overhead and Underground Hazards: Before work starts on any jobsite, all over-head obstructions such as power lines and low clearance should be identified and flagged.

Look Out for Overhead Powerlines: Although not a typical struck-by incident, contact with overhead powerlines has been a major cause of fatalities and critical injuries in construction. These types of incidents usually involve heavy equipment such as backhoes, dump trucks, boom trucks, cranes, and excavators (ihsa.ca, 2018; nektardata.com, 2018).

In addition to the general measures mentioned above, the following special measures should be taken.

- Machines suitable for the work should be selected.

- Periodic maintenance of the machines in the construction site should be done.

- Workers should not be employed in the movement areas of the machines.

- On the machine, there should be no one other than the operator.

- Sufficient working distance should be left around the rotatable vehicles.

- Workers who use the machine must be given a seat belt.

- There should be sound and light stimulus systems on the machines.

- Workers should not be brought close to the machines that are in danger of falling or tipping.

- Areas under the risk of possible dumping in the construction site should be identified in advance and heavy tonnage construction machinery should not be placed in these areas.

- Care should be taken to ensure that there are no objects or structures to obstruct vision in the excavation areas.

- In the case of night work, especially the areas where construction machinery will work should be well lighted (Altınöz 2011; HSE, 2018; OSHA, 2018). 


\section{Results}

Firstly, a strict training and strong adaptation work are necessary for workers, especially the inexperienced and operators. An effective monitoring and warning system is then needed to control the movement and operation of the equipment (selection, repair, operation, etc.). For this purpose, attention should be given to safe equipment technology, that is, approach warning systems, automation, GPS and radar based warning systems, communication between teams, remote control equipment and training of operators who will use these machines. In addition to these, there is a need for a management and organization, a strict education-training program, the follow-up of technological developments in safety equipment, the implementation or follow-up of the most successful and safe practices and the compliance with mandatory regulations. As a result, equipment safety technology research and applications should be followed violently. In addition, all stakeholders responsible for occupational health and safety; If they pay particular attention to the use of safety technologies, the use of machinery and personal protection, education, and adoption of a culture of occupational safety, both equipment-related accidents and other occupational accidents will be reduced to the lowest levels.

\section{References}

[1] Altınöz, H., Uzun, M., Bahadır, Y., Sarmusak, F., Karagöz, Y. Yapı Makinaları Kullanımında Sıklıkla Karşılaşılan İş Kazaları ve Alınması Gereken Önlemler. 3. İşçi Sağlığı ve İş Güvenliği Sempozyumu, 21-23 Ekim 2011, Çanakkale, 61-73.

Reference to a book:

[2] https://www.osha.gov/Publications/OSHA3170/osha3170.html

[3] http://www.hse.gov.uk/work-equipment-machinery/maintenance.htm

[4] Strunk Jr W, White EB. The elements of style. 3rd ed. New York: Macmillan; 1979.

[5] Marsh, S.M., Fosbroke, D.E. (2015). Trends of Occupational Fatalities Involving Machines, United States, 1992-2010. American Journal of Industrial Medicine, 58(11), 1160-1173.

[6] McCann, M. (2006). Heavy equipment and truck-related deaths on excavation work sites. Journal of Safety Research, 37, 511-517.

[7] Ihsa.ca., 2018. Infrastructure Health \& Safety Association. Health and safety advisory Working Safely On or Around Heavy Equipment.

[8] https://www.osha.gov/SLTC/etools/construction/index.html

[9] https://arlweb.msha.gov/equipmentsafety/equipmentaccidents.asp

[10] Ihsa.ca., 2018. Infrastructure Health \& Safety Association. Struck-By Incidents and Heavy Equipment.

[11] The Bureau of Labor Statistics (2016). Census of Fatal Occupational Injuries. https://www.bls.gov/iif/oshcfoi1.htm\#2016

Note shortened form for last page number. e.g., 51-9, and that for more than 6 authors the first 6 should be listed followed by "et al." For further details you are referred to "Uniform Requirements for Manuscripts submitted to Biomedical Journals" (J Am Med Assoc 1997;277:927-934) 